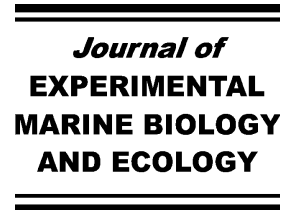

Journal of Experimental Marine Biology and Ecology 326 (2005) 115-127

www.elsevier.com/locate/jembe

\title{
Annual production of estuarine fauna in different environmental conditions: An evaluation of the estimation methods
}

\author{
M. Dolbeth*, A.I. Lillebø, P.G. Cardoso, S.M. Ferreira, M.A. Pardal \\ Institute of Marine Research (IMAR), c/o Department of Zoology, University of Coimbra, 3004-517 Coimbra, Portugal
}

Received 16 November 2004; received in revised form 20 May 2005; accepted 20 May 2005

\begin{abstract}
Secondary production is one of the most comprehensive measurements of ecosystem health. Production of five estuarine species, with different life history and abundance in the ecosystem, was estimated for 2 consecutive years at a Zostera noltii bed and sand-muddy area, with contrasted environmental conditions. Calculations were performed using different estimation methods, commonly cited in secondary production studies. Annual production estimated by cohort increment summation varied between 43.3 and $209.2 \mathrm{~g} \mathrm{AFDW} \mathrm{m}^{-2} \mathrm{y}^{-1}$. All the other methods were compared with the results obtained from this methodology to evaluate each method's performance. In general, satisfactory results were obtained with Brey (2001) [Brey, T., 2001. Population dynamics in benthic invertebrates. A virtual handbook. Version 01.2. http:// www.awi-bremerhaven.de/Benthic/Ecosystem/FoodWeb/Handbook/main.html. Alfred Wegener Institute for Polar and Marine Research, Germany] version 4-04 (deviations that ranged between -4 to $+10 \%$ ). The responses of the other empirical methods were more variable, depending on the species characteristics. Therefore, the optimal selection of an empirical method in secondary production studies depends on the species considered and on the quality of the parameters required for the application of the method. Brey (2001) [Brey, T., 2001. Population dynamics in benthic invertebrates. A virtual handbook. Version 01.2. http://www.awi-bremerhaven.de/Benthic/Ecosystem/FoodWeb/Handbook/main.html. Alfred Wegener Institute for Polar and Marine Research, Germany] version 4-04 was considered the best methodology. For the less representative species the simple sum of biomass increments from one sampling date to the next may be an easy and valid option.
\end{abstract}

(C) 2005 Elsevier B.V. All rights reserved.

Keywords: Cohort increment summation; Empirical methods; Eutrophication; Macrobenthic production

\footnotetext{
* Corresponding author. Fax: +351 239823603.

E-mail address: mdolbeth@ci.uc.pt (M. Dolbeth).
}

\section{Introduction}

Somatic production of macrozoobenthic populations is an important parameter for the study of ecosystem dynamics. It is a quantitative measure of population function in the ecosystem, being often

0022-0981/\$ - see front matter (C) 2005 Elsevier B.V. All rights reserved. doi:10.1016/j.jembe.2005.05.010 
used to assess environmental stress, rational management of biological resources, energy flow, organic matter cycling and food web interactions (Waters and Crawford, 1973; Cushman et al., 1978; Benke, 1984, 1993; Crisp, 1984; Morin et al., 1987; Tumbiolo and Downing, 1994). Moreover, it may acquire economic importance, when related with fish and shellfish yield (Waters and Crawford, 1973; Crisp, 1984; Brey, 1990a).

For long time, methods based on the recognition of cohorts have been considered to provide accurate evaluation of secondary production (Waters and Crawford, 1973; Cushman et al., 1978; Benke, 1993; Sprung, 1993; Medernach, 1999; Brey, 2001). Whenever cohorts are not recognizable, size frequency and mass specific growth rate methods have been applied (Benke, 1984; Brey, 2001). Nevertheless, estimations made by these methods are time consuming and often data are not available (Brey, 1990a; Sprung, 1993, 1994; Medernach, 1999; Dolbeth et al., 2003).

In order to find an easier yet reliable way to estimate secondary production, many authors have tried to establish methods based on empirical relationships (Robertson, 1979; Banse and Mosher, 1980; Schwinghamer et al., 1986; Brey, 1990a; Morin and Bourassa, 1992; Benke, 1993; Sprung, 1993; Tumbiolo and Downing, 1994; Brey, 2001). These methods are based on good correlations found between population (e.g., life span, maximum individual weight, mean individual weight, mean biomass) or environment (e.g., temperature, depth) characteristics and secondary production or $P / \bar{B}$ ratio (Medernach, 1999; Brey, 2001). Still, estimates obtained by these methods must be analysed cautiously, as they may be misleading in certain cases (Sprung, 1993; Morin, 1997; Medernach, 1999; Brey, 2001; Mistri et al., 2001).

In the present study, secondary production was estimated and compared using cohort increment summation and empirical methods for five species whose lifestyles are representative of taxa generally found in intertidal flats. First, the secondary production was estimated by cohort increment summation and computed in order to: a) provide reference values of the species production in different habitats, b) understand the production variations in the different habitats and environments; second, secondary production was estimated by empirical methods in order to: c) understand the performance of each empirical method for different species and habitats; d) find the best alternative methodology to estimate secondary macrobenthic production in temperate estuaries.

\section{Material and methods}

\subsection{Study site and sampling}

The Mondego estuary (Portugal) is located in a warm temperate region $\left(40^{\circ} 08^{\prime} \mathrm{N}, 8^{\circ} 50^{\prime} \mathrm{S}\right)$ and has two arms. Anthropogenic activities in the estuary have been the cause of high environmental pressure, which has resulted in persistent eutrophication over the past two decades. The downstream areas of the south arm still remain relatively unchanged, exhibiting Zostera noltii meadows, whereas in the inner parts, the seagrass community has completely disappeared and Ulva sp. blooms have been observed (Lillebø et al., 1999; Pardal et al., 2000, 2004; Cardoso et al., 2002, 2004; Dolbeth et al., 2003; Ferreira et al., 2004).

Sampling occurred fortnightly from February 1993 to June 1994 and monthly until February 1995, at low tide in the Mondego estuary south arm. Two sites were considered: a) non-eutrophic area, Zostera noltii bed and b) eutrophic area, a sand-flat where an Ulva sp. bloom occurred in the spring 1993, followed by the algal crash in July 1993. On each sampling occasion, 6 to 10 cores $\left(141 \mathrm{~cm}^{2}\right)$ were taken to a depth of $20 \mathrm{~cm}$. Samples were washed in $500 \mu \mathrm{m}$ mesh sieve bags. At the laboratory, the biological material was separated and preserved in a $4 \%$ buffered formalin solution. In the present study, five intertidal benthic species were used: a) Hydrobia ulvae (Gastropoda), dominant species at the Zostera bed; b) Cyathura carinata (Isopoda), dominant species at the eutrophic area; c) Scrobicularia plana (Bivalvia), more abundant at the eutrophic area and d) Ampithoe valida and Melita palmata (Amphipoda), less abundant species in both areas. All individuals were counted, measured and their ash-free dry weight (AFDW) assessed after combustion for $8 \mathrm{~h}$ at $450{ }^{\circ} \mathrm{C}$. Together, these species account for $80-90 \%$ of the total macrobenthic production in the Mondego estuary (Dolbeth et al., 2003). 


\subsection{Secondary production}

Secondary production was estimated by the increment summation method (Cohort, Table 1), after recognition of the cohorts following the procedure of Lillebø et al. (1999); Pardal et al. (2000, 2002), Cardoso et al. (2002), Ferreira et al. (2004), Verdelhos et al. (2005). All cohorts were recognized through size-frequency distribution analysis of successive sampling dates, performed with ANAMOD software (Nogueira, 1992). The production estimates of $S$. plana were made for individuals larger than $4 \mathrm{~mm}$.
These results (Cohort) were used as a reference to be compared with the estimates of the empirical methods.

Six empirical methods, commonly used in secondary production studies, were selected for estimate comparisons. The sum of biomass from one sampling date to next (Inc Sum) was also considered. All methods equations and symbols used in the text are presented in Table 1. The data required for the application of the empirical methods are presented in Table 2. Life spans (Table 2) were referred in Cardoso et al. (2002), Pardal et al. (2000, 2002), Ferreira et al. (2004), Verdelhos et al. (2005).

Table 1

Methods used for the computation of secondary production, with reference to the method symbol and equation units

\begin{tabular}{|c|c|c|c|c|}
\hline Method & & Equation & Symbol & Units \\
\hline Cohort method & $\begin{array}{l}\text { Increment } \\
\text { summation } \\
\text { Winberg (1971) }\end{array}$ & $P=\sum_{t=0}^{t=n}\left(\frac{N_{t}+N_{t+1}}{2}\right) \times\left(\bar{w}_{t+1}-\bar{w}_{t}\right)$ & Cohort & $\begin{array}{l}\mathrm{N}, \text { ind } \mathrm{m}^{-2} ; \bar{w} \\
\mathrm{~g} \mathrm{AFDWm}^{-2}\end{array}$ \\
\hline \multirow{7}{*}{$\begin{array}{l}\text { Empirical } \\
\text { methods }\end{array}$} & Robertson (1979) & $\log P / \bar{B}=0.66-0.726 \log L$ & Robert & $L$, years \\
\hline & $\begin{array}{l}\text { Schwinghamer } \\
\text { et al. (1986) }\end{array}$ & $P / \bar{B}=0.525 \bar{w}^{-0.304}$ & Schw & $\begin{array}{l}\bar{B} \text { and } \bar{w}, \text { Kcal } \\
\mathrm{m}^{-2} ; \Delta t \text {, days }\end{array}$ \\
\hline & Sprung (1993) & $P_{\Delta t}=\left(\frac{P / \bar{B}_{\text {spec }}}{365} / \bar{w}_{-0.25}\right) \times \bar{w}_{\Delta t}^{-0.25} \times \bar{B}_{\Delta t} \times \Delta t$ & Sprung 1, 2 & $\begin{array}{l}\bar{w} \text { and } w_{\text {ind }}, \mathrm{g} \\
\text { AFDW m }{ }^{-2} ; \Delta t \\
\text { days }\end{array}$ \\
\hline & $\begin{array}{l}\text { Morin and } \\
\text { Bourassa (1992) }\end{array}$ & $\log P=-0.75+1.01 \log \bar{B}-0.34 \log \bar{w}+0.037 \times \bar{T}$ & $M \& B$ & $\begin{array}{l}B \text { and } w, \mathrm{~g} \mathrm{DW} \\
\mathrm{m}^{-2} ; T,{ }^{\circ} \mathrm{C}\end{array}$ \\
\hline & $\begin{array}{l}\text { Tumbiolo and } \\
\text { Downing (1994) }\end{array}$ & $\log P=0.18+0.97 \log \bar{B}-0.22 \log w+0.04 \bar{T}-0.014 \bar{T} \log (D+1)$ & $T \& D$ & $\begin{array}{l}\bar{B}, \mathrm{~g} \mathrm{DW} \mathrm{m}^{-2} ; \\
w_{\mathrm{m}}, \mathrm{mg} \mathrm{DW} \mathrm{m}^{-2} \\
T,{ }^{\circ} \mathrm{C} ; D, \mathrm{~m} ; \Delta t \\
\text { days }\end{array}$ \\
\hline & Brey (2001) & $\begin{aligned} \log P / \bar{B}= & 7.947(-2.294 \log w-2409.856 \times(1 /(T+273))+0.168 \\
& \times(1 / D)+0.180 \text { SubT }+0.180 \ln E p i+0.277 \text { MoEpi } \\
& +0.174 \text { Taxon } 1-0.188 \text { Taxon } 2+0.33 \text { Taxon } 3 \\
& -0.062 \text { Habitat } 1+582.851 \times(\log w \times(1 /(T+273)))\end{aligned}$ & Brey 4-04 & $\begin{array}{l}w, \mathrm{kcal} \mathrm{m}^{-2} ; T \\
\mathrm{~K} ; D, \mathrm{~m}\end{array}$ \\
\hline & $\begin{array}{l}\text { "Simple increment } \\
\text { summation" }\end{array}$ & $\begin{array}{l}\text { Sum of the increases in biomass from one sampling date } \\
\text { to the next (application of the equation cohort, without the } \\
\text { recognition of cohorts) }\end{array}$ & Inc Sum & $\begin{array}{l}N, \text { ind } \mathrm{m}^{-2} ; \bar{w}, \mathrm{~g} \\
\text { AFDWm }^{-2}\end{array}$ \\
\hline
\end{tabular}

$P$, production; $B$, mean biomass; $N$, mean density; $\bar{w}$, mean individual body weight; $w_{\mathrm{m}}$, maximum individual body weight; $t, t+1$, consecutive sampling dates $(t=1,2, \ldots, n) ; \Delta t$, difference between sampling dates; $P / \bar{B}_{\text {spec }}$, estimate of the typical $P / \bar{B}$ of the species; $L$, lifespan; $T$, mean bottom water temperature; $D$, mean depth; SubT, subtidal $(S u b T=1)$ or intertidal $(S u b T=0)$; InFau, infauna $(\operatorname{InFau}=1)$ or epifauna $(\operatorname{InFau}=0)$; $M o E p i$, motile epifauna $(M o E p i=1)$ or not $(M o E p i=0)$; Taxon1, Annelida or Crustacea $(\operatorname{Taxon} 1=1)$ or other taxon $($ Taxon1=0); Taxon2, if Echinodermata (Taxon2 $=1$ ) or other taxon (Taxon2=0); Taxon3, if Insecta (Taxon3=1) or other taxon (Taxon3=0); Habitat1, lake $($ Habitat $1=1)$ or other habitat $($ Habitat $1=0)$. 
Table 2

Data used for the application of the empirical methods. $\bar{B}$, mean biomass; $\bar{w}$, mean body weight; $w_{\mathrm{m}}$, maximum individual body weight; $P / \bar{B}$ spec, estimate of the typical $P / \bar{B}$ of the species; $L$, lifespan; $T$, mean bottom temperature

\begin{tabular}{|c|c|c|c|c|c|c|}
\hline & & H. ulvae & C. carinata & S. plana & A. valida & M. palmata \\
\hline \multirow[t]{7}{*}{ GENERAL } & 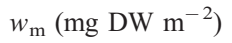 & 96.9 & 67.0 & 6870.9 & 4.1 & 6.1 \\
\hline & L (months) & 16 to 20 & 23 to 24 & 62 & 7 to 9 & 4 to 7 \\
\hline & $\mathrm{P} / \bar{B}_{\text {spec }} 2$ & 3.37 & 2.64 & 2.53 & 3.92 & 3.28 \\
\hline & DW & $16.104 \times$ & $1.2003 \times$ & $18.054 \times$ & $1.0976 \times \mathrm{AFDW}-$ & $1.1623 \times$ \\
\hline & & AFDW - 1.084 & AFDW - 0.00004 & AFDW -0.0031 & 0.0000008 & AFDW -0.000003 \\
\hline & AFDW & $0.0589 \times \mathrm{DW}+$ & $0.8258 \times \mathrm{DW}+$ & $0.0546 \times \mathrm{DW}+$ & $0.8258 \times \mathrm{DW}+$ & $0.826 \times \mathrm{DW}+$ \\
\hline & & 0.00986 & 0.00004 & 0.0003 & 0.00004 & 0.000005 \\
\hline \multirow[t]{4}{*}{ Zostera 1993} & $\bar{B}\left(\mathrm{~g} \mathrm{AFDW} \mathrm{m}^{-2}\right)$ & 56.0 & 0.0862 & 2.19 & 0.964 & 0.0606 \\
\hline & $\bar{w}\left(\mathrm{~g}^{\mathrm{AFDW}} \mathrm{m}^{-2}\right)$ & 0.000982 & 0.00203 & 0.0474 & 0.000396 & 0.000238 \\
\hline & $\mathrm{P} / \bar{B}_{\text {spec }} 1$ & 2.07 & 3.61 & 2.39 & 4.86 & 5.87 \\
\hline & $\mathrm{T}\left({ }^{\circ} \mathrm{C}\right)$ & 17.7 & 17.7 & 17.7 & 17.7 & 17.7 \\
\hline \multirow[t]{4}{*}{ Zostera 1994} & $\bar{B}\left(\mathrm{~g}\right.$ AFDW $\left.\mathrm{m}^{-2}\right)$ & 67.1 & 1.12 & 2.01 & 0.0733 & 0.219 \\
\hline & $\bar{w}\left(\mathrm{~g}_{\mathrm{AFDW}} \mathrm{m}^{-2}\right)$ & 0.000865 & 0.00710 & 0.00732 & 0.000346 & 0.000206 \\
\hline & $\mathrm{P} / \bar{B}_{\text {spec }} 1$ & 2.73 & 3.61 & 0.42 & 4.18 & 3.78 \\
\hline & $\mathrm{T}\left({ }^{\circ} \mathrm{C}\right)$ & 19.7 & 19.7 & 19.7 & 19.7 & 19.7 \\
\hline \multirow[t]{4}{*}{ Eutrophic 1993} & $\bar{B}\left(\mathrm{~g} \mathrm{AFDW} \mathrm{m}^{-2}\right)$ & 9.49 & 7.22 & 10.3 & 0.123 & 0.0864 \\
\hline & $\bar{w}\left(\mathrm{~g} \mathrm{AFDW} \mathrm{m}^{-2}\right)$ & 0.000225 & 0.00400 & 0.0840 & 0.000192 & 0.000125 \\
\hline & $\mathrm{P} / \bar{B}_{\text {spec }} 1$ & 4.82 & 3.53 & 1.34 & 3.65 & 5.80 \\
\hline & $\mathrm{T}\left({ }^{\circ} \mathrm{C}\right)$ & 21.5 & 21.5 & 21.5 & 21.5 & 21.5 \\
\hline \multirow[t]{4}{*}{ Eutrophic 1994} & $\bar{B}\left(\mathrm{~g} \mathrm{AFDW} \mathrm{m}^{-2}\right)$ & 1.78 & 9.60 & 4.04 & 0.00144 & 0.00802 \\
\hline & $\bar{w}\left(\mathrm{~g}\right.$ AFDW $\left.\mathrm{m}^{-2}\right)$ & 0.000199 & 0.00488 & 0.0415 & 0.0000682 & 0.0000311 \\
\hline & $\mathrm{P} / \bar{B}_{\text {spec }} 1$ & 4.52 & 2.98 & 0.12 & 8.88 & 3.67 \\
\hline & $\mathrm{T}\left({ }^{\circ} \mathrm{C}\right)$ & 20.0 & 20.0 & 20.0 & 20.0 & 20.0 \\
\hline
\end{tabular}

For the application of Sprung (1993) method, an alternative equation was used (following previous instructions from the author). Two $P / \bar{B}_{\text {spec }}$ were tested: one calculated from the Cohort results, named as $P / \bar{B}_{\text {spec }} 1$ (Sprung 1); and the other estimated as the mean of $P / \bar{B}$ ratios found in literature, for the same species in other temperate regions and similar environments, named as $P / \bar{B}_{\text {spec }} 2$ (Sprung 2). In Tumbiolo and Downing (1994) method (T\&D), a $0 \mathrm{~m}$ depth was considered, according to the suggestion of the authors for intertidal species. The estimates obtained by the model of Brey (2001) were done using the model version 4-04 available on his computation spreadsheet (Brey 4-04).

Final results were all converted to $\mathrm{g}$ AFDW $\mathrm{m}^{-2}$ $\mathrm{y}^{-1}$. In Schw the conversion used was: $1 \mathrm{~g} \mathrm{AFDW}=5.6$ Kcal (Winberg, 1971). In Brey 4-04, the conversions used were: H. ulvae, $1 \mathrm{~g}$ AFDW=23.04 kJ; C. carinata, A. valida, M. palmata, $1 \mathrm{~g}$ AFDW $=.74 \mathrm{~kJ} ; S$. plana, $1 \mathrm{~g} \mathrm{AFDW}=22.79 \mathrm{~kJ}$ (Brey, 2001).

For each method, 20 annual estimates $(5$ species $\times 2$ areas $\times 2$ years) were obtained. The quality and patterns of deviation of each empirical method were checked by a linear regression model II, Major Axis Regression method (Sokal and Rohlf, 1981), of the empirical method estimates versus cohort increment summation estimates, i.e., Empirical_method= $a+b^{*}$ Cohort_method, for $n=20$. Model II regression was applied as both variables are subjected to error (Sokal and Rohlf, 1981). The $H_{0}$ was of no deviation between Cohort and empirical method occurs when simultaneously the intercept $=0$ and slope $=1$, which was tested with a Dent and Blackie test, using $F$-test with 2 and $(n-2)$ degrees of freedom (Tedeschi, 2004).

\section{Results}

\subsection{Annual community production}

Annual production was always higher in the Zostera bed (Fig. 1, Table 3). In 1993, the Zostera bed showed lower production, followed by a substantial increase in 1994. For the eutrophic area, production was higher in 1993 (macroalgal bloom year), but 

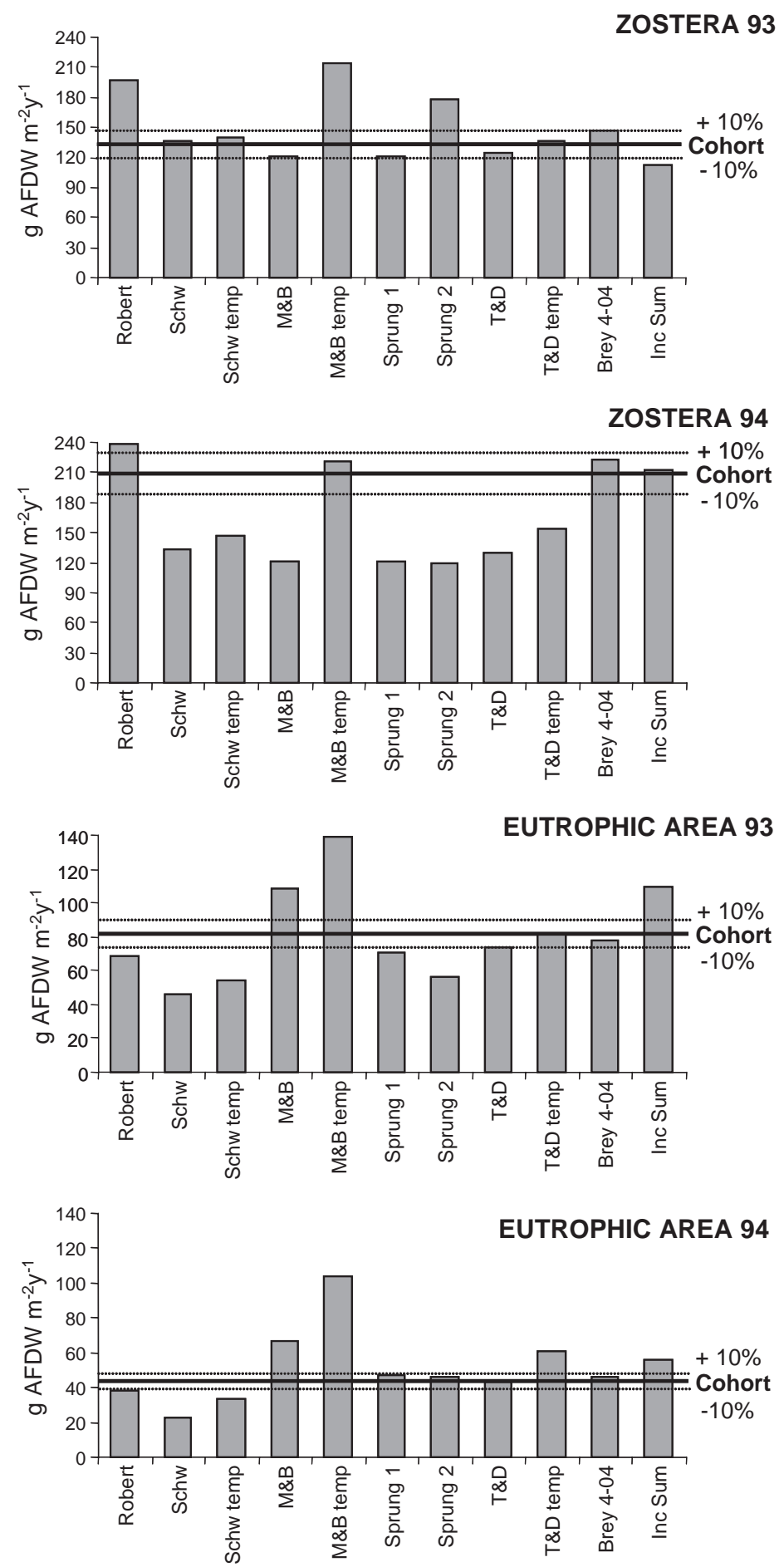

Fig. 1. Annual production estimates of the 5 species community, with indication of the $10 \%$ of deviation to the cohort increment summation estimates. 
Table 3

Annual production estimates for the different species, by the different methods

\begin{tabular}{|c|c|c|c|c|c|c|c|}
\hline & & H. ulvae & C. carinata & S. plana & A. valida & M. palmata & Total \\
\hline \multirow[t]{9}{*}{ ZOSTERA 93} & Cohort & 124.9 & 0.4 & 6.6 & 0.4 & 0.4 & 132.6 \\
\hline & Robert & 192.2 & 0.2 & 3.0 & 0.6 & 0.6 & 196.7 \\
\hline & Schw & 134.4 & 0.2 & 1.7 & 0.3 & 0.2 & 136.8 \\
\hline & $M$ and $B$ & 114.4 & 1.9 & 1.8 & 1.1 & 1.1 & 120.3 \\
\hline & Sprung 1 & 115.4 & 0.3 & 5.1 & 0.5 & 0.3 & 121.6 \\
\hline & Sprung 2 & 171.3 & 0.2 & 5.4 & 0.4 & 0.3 & 177.5 \\
\hline & $T$ and $D$ & 120.4 & 0.3 & 2.2 & 0.6 & 0.3 & 123.8 \\
\hline & Brey 4-04 & 144.0 & 0.3 & 1.5 & 0.03 & 0.4 & 146.1 \\
\hline & Inc Sum & 101.6 & 0.5 & 10.2 & 0.2 & 0.2 & 112.6 \\
\hline \multirow[t]{9}{*}{ ZOSTERA 94} & Cohort & 202.5 & 3.2 & 1.2 & 0.3 & 2.0 & 209.2 \\
\hline & Robert & 230.2 & 3.1 & 2.8 & 0.4 & 1.6 & 238.2 \\
\hline & Schw & 127.9 & 1.5 & 2.8 & 0.2 & 0.8 & 133.1 \\
\hline & $M$ and $B$ & 108.2 & 3.9 & 4.0 & 1.0 & 4.3 & 121.5 \\
\hline & Sprung 1 & 113.8 & 3.4 & 1.0 & 0.2 & 1.7 & 120.1 \\
\hline & Sprung 2 & 109.1 & 3.3 & 5.9 & 0.3 & 1.1 & 119.5 \\
\hline & $T$ and $D$ & 121.1 & 4.0 & 2.3 & 0.5 & 1.4 & 129.3 \\
\hline & Brey 4-04 & 215.1 & 2.8 & 2.7 & 0.0 & 1.6 & 222.2 \\
\hline & Inc Sum & 200.3 & 2.9 & 7.8 & 0.2 & 0.5 & 211.8 \\
\hline \multirow[t]{9}{*}{ EUTROPHIC 93} & Cohort & 45.4 & 23.7 & 11.2 & 0.4 & 0.7 & 81.6 \\
\hline & Robert & 32.6 & 20.3 & 14.1 & 0.8 & 0.7 & 68.5 \\
\hline & Schw & 27.3 & 11.7 & 6.6 & 0.4 & 0.4 & 46.3 \\
\hline & $M$ and $B$ & 47.6 & 43.0 & 12.0 & 2.4 & 3.5 & 108.5 \\
\hline & Sprung 1 & 42.7 & 23.8 & 2.9 & 0.4 & 0.4 & 70.2 \\
\hline & Sprung 2 & 31.8 & 18.0 & 5.5 & 0.4 & 0.2 & 55.9 \\
\hline & $T$ and $D$ & 30.2 & 28.1 & 13.6 & 1.1 & 0.7 & 73.7 \\
\hline & Brey 4-04 & 47.1 & 22.4 & 6.8 & 1.0 & 0.8 & 78.0 \\
\hline & Inc Sum & 29.9 & 25.4 & 53.3 & 0.5 & 0.5 & 109.6 \\
\hline \multirow[t]{9}{*}{ EUTROPHIC 94} & Cohort & 10.9 & 32.0 & 0.4 & 0.01 & 0.04 & 43.3 \\
\hline & Robert & 6.1 & 26.9 & 5.5 & 0.01 & 0.07 & 38.7 \\
\hline & Schw & 5.2 & 14.4 & 3.1 & 0.01 & 0.04 & 22.7 \\
\hline & $M$ and $B$ & 11.7 & 50.7 & 4.1 & 0.03 & 0.21 & 66.8 \\
\hline & Sprung 1 & 11.9 & 34.8 & 0.3 & 0.00 & 0.02 & 47.1 \\
\hline & Sprung 2 & 8.9 & 29.7 & 7.4 & 0.00 & 0.06 & 46.0 \\
\hline & $T$ and $D$ & 5.2 & 33.2 & 4.9 & 0.01 & 0.06 & 43.4 \\
\hline & Brey 4-04 & 10.6 & 31.5 & 3.6 & 0.02 & 0.13 & 45.9 \\
\hline & Inc Sum & 2.5 & 30.3 & 22.8 & 0.01 & 0.06 & 55.6 \\
\hline
\end{tabular}

decreasing considerably (almost half) in the following year (Figs. 1, 2, Table 3).

The most consistent estimates of annual production were obtained with Brey 4-04, with good results for both areas and years (deviations lower than $10 \%$, Fig. 1). The linear regression resulted in a slope close to 1 and intercept close 0 (Fig. 3), yet, the Dent and Blackie test generated significant differences $(F=$ $21.1, p>0.05$ ), mainly due to the small mean square error $(\mathrm{MSE}=11)$ obtained with this method. The other empirical methods presented more variable responses. Sprung 1 estimates were comparatively good for annual production with deviations near $10 \%$, but quite high for the Zostera bed in 1994 (-43\%, Fig. 1), and regression line parameters were significantly different from 1 and 0 (Fig. 3; $F=11.6, p>0.05$ ). Also, higher deviations could be reached with Sprung 2 (Fig. 1). Its regression line parameters differed from 1 and 0 , along with a low determination coefficient $\left(R^{2}=0.78\right.$, Fig. 3), yet no significant differences were found $(F=1.1, p<0.05)$, mainly due to the high mean square error $(\mathrm{MSE}=455)$, increasing its tolerance (Tedeschi, 2004). Robert produced estimates with deviations also close to $10 \%$, with the exception of the Zostera bed in 1993 (+49\%, Fig. 1). The estimates provided by Inc Sum were reasonable for 

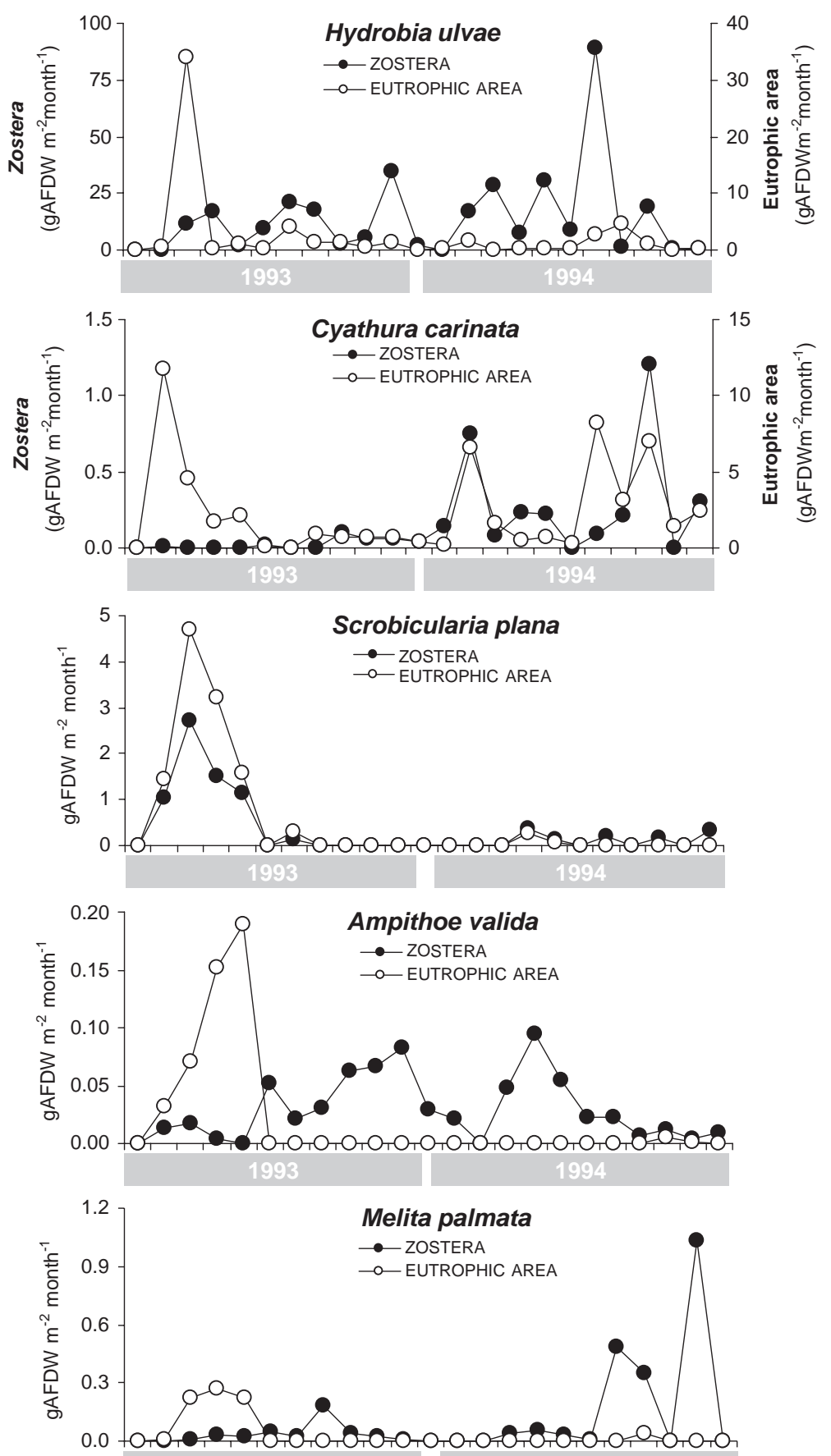

Fig. 2. Monthly variation of the secondary production estimated by the cohort increment summation method, for each species and both areas. 

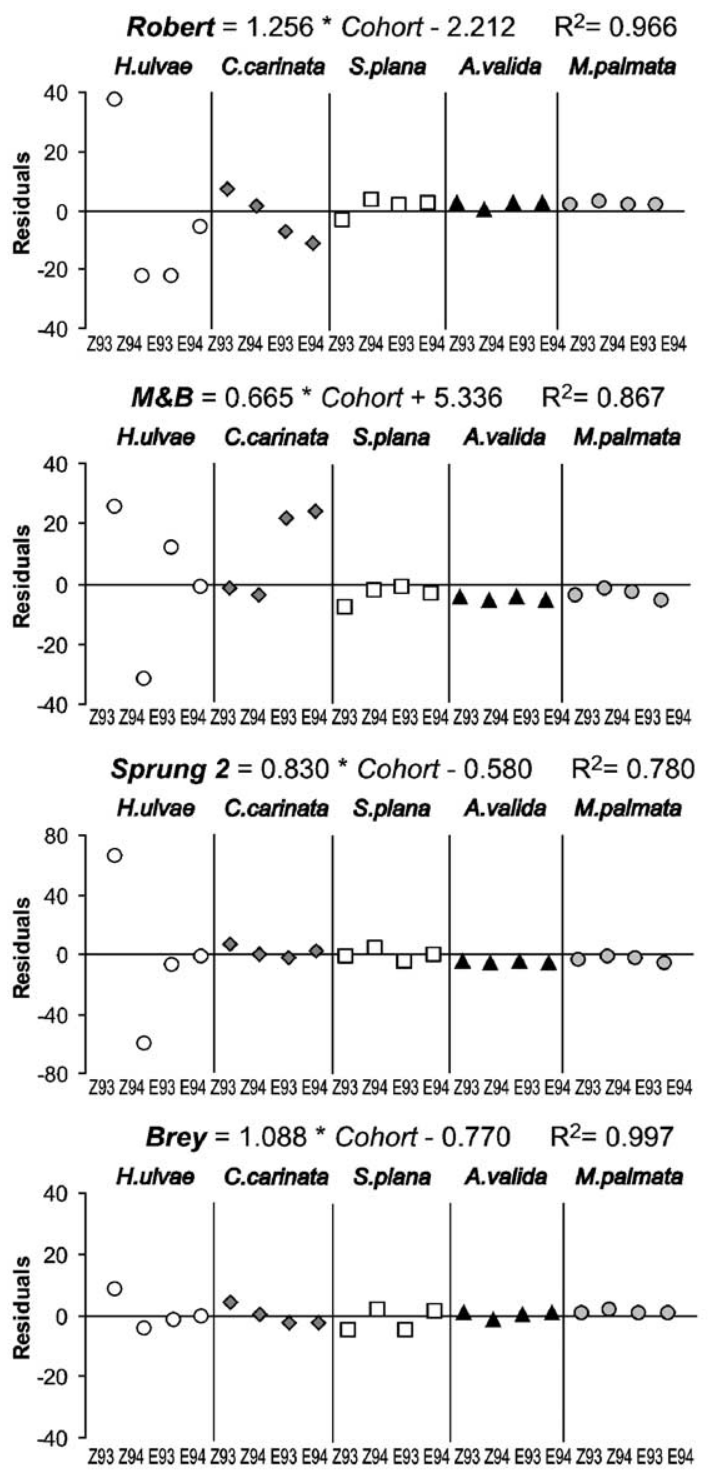
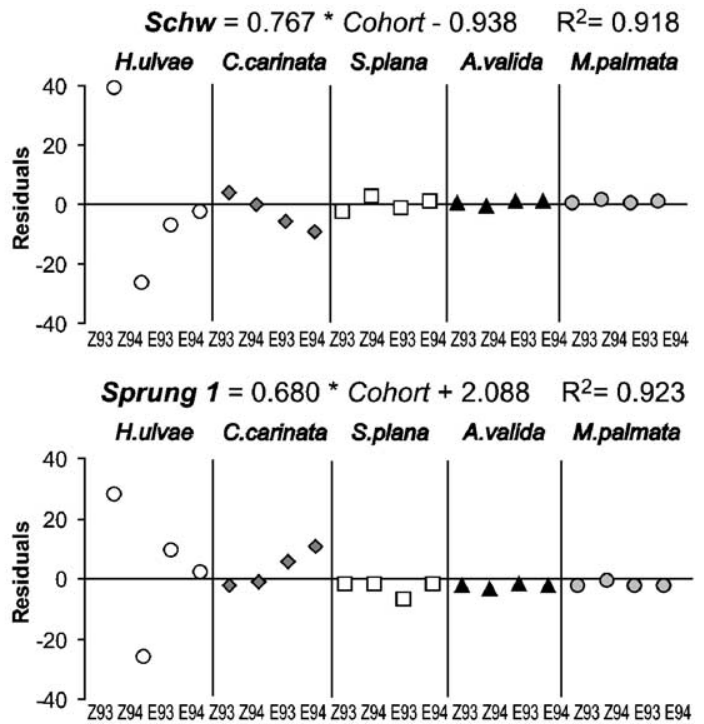

$T \& D=0.547$ * Cohort $+2.816 \quad \mathrm{R}^{2}=0.914$

H.ulvae C.carinata S.plana A.valida M.palmata

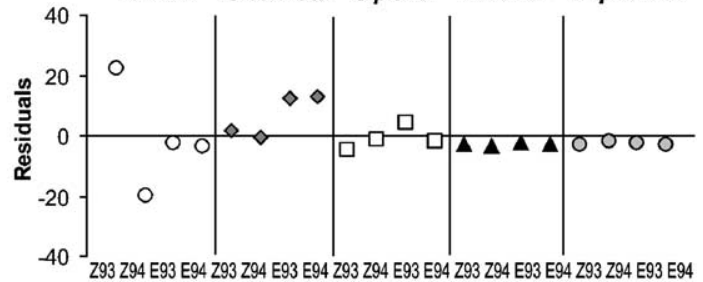

Inc Sum $=0.944$ * Cohort $+2.456 \quad \mathrm{R}^{2}=0.937$

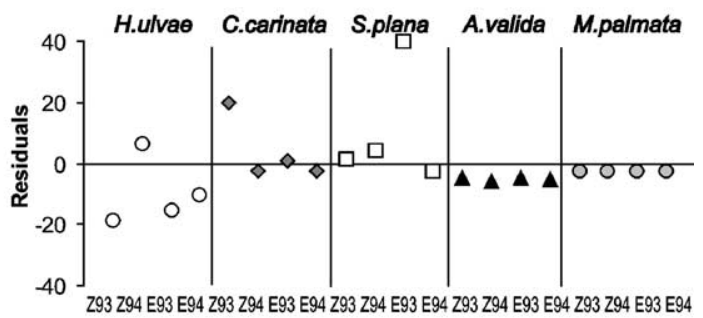

Fig. 3. Residuals from the linear regression model II analysis of Cohort method versus empirical method provided for the 20 annual estimates $(5$ species $\times 2$ areas $\times 2$ years), with indication of the regression line parameters.

the Zostera bed, but over-estimated for the eutrophic area (Fig. 1). In general, $S c h w$ and $T \& D$ produced under-estimations and $M \& B$ showed a tendency for over-estimation (Fig. 1). These three last methods showed the highest deviations among the empirical methods tested (Fig. 1). Dent and Blackie test proved significant differences in the slopes and intercepts $(p>0.05)$ for Robert $(F=16.7$; MSE $=151), S c h w$ $(F=6.8 ; \quad \mathrm{MSE}=137), \quad M \& B \quad(F=6.5 ; \quad \mathrm{MSE}=174)$ and $T \& D(F=20.6 ; \mathrm{MSE}=75)$. Inc Sum had a slope near 1 but a relatively high intercept (Fig. 3), although no significant differences were found $(F=0.5, p<$ 0.05 ; $\mathrm{MSE}=159)$, and yet again the mean square error was quite high (Tedeschi, 2004).

Schw, M\&B and Inc Sum methods gave better results for the Zostera bed than for the eutrophic area, which were hugely over-estimated with $M \& B$ and under-estimated with the other two methods (Fig. 
1, Table 3). Instead, Robert, Sprung 2 and $T \& D$ produced better estimates for the eutrophic area (Table 3). Nevertheless, for almost all methodologies in study, the estimates for the Zostera bed in 1994 could reach very high deviations.

\subsection{Different species production}

With the exception of $C$. carinata (dominant in the eutrophic area), all species had higher production in the Zostera bed (Fig. 2, Table 3). H. ulvae always attained the higher production, with exception of the eutrophic area in 1994, when C. carinata production was higher (Fig. 2, Table 3). In 1994, production increased substantially in the Zostera bed for $H$. ulvae, C. carinata and A. valida, decreasing for $S$. plana and M. palmata (Fig. 2, Table 3). By contrast, in the eutrophic area, all species showed an initial increase in production during the spring of 1993, followed by a considerable decrease in late summer (Fig. 2), varying along with the macroalgal biomass dynamics. In this area, the production values remained low during the rest of the study period, with the exception of $C$. carinata (Fig. 2).

None of the methods responded well for all each species analysed. Nevertheless, Brey 4-04 and Sprung 1 can be pointed as providing the most consistent results for annual production (Table 3), with generally low residuals, exception for $H$. ulvae in Zostera under Sprung 1 (Fig. 3). Yet, for the less abundant species (A. valida and M. palmata), deviations could be considerable high, mainly due to very low production values (e.g., deviations of $492 \%$ to $530 \%$, Table 3).

With the other methods the responses were highly variable (Table 3). In general, for all methods, higher residuals were obtained for the more representative species, especially H. ulvae in Zostera and eutrophic area 1993, followed by C. carinata in the eutrophic area and Zostera 1993, and for S. plana especially with Inc Sum (Fig. 3). Lower residuals were observed for the less abundant species, A. valida and M. palmata. Yet, $M \& B$ showed high residuals for these species (Fig. 3), associated with the over-estimated productions (Table 3).

Scrobicularia plana was the species with the worst results, with deviations that could reach more than $1000 \%$ in the eutrophic area, due to the low produc- tion absolute value (Table 3). In general, Sprung and Schw temp gave under-estimations, while $M \& B, T \& D$ and Inc Sum largely over-estimated production. This last method showed quite high residual in the eutrophic area (Fig. 3).

\section{Discussion}

\subsection{Methodological comparisons}

Production estimated by increment summation method was always higher in the Zostera bed. Species seemed to take advantage of the seagrass coverage, either by food or protection, to enhance their production (Edgar et al., 1994; Sprung, 1994; Heck et al., 1995; Cardoso et al., 2002, 2004; Dolbeth et al., 2003; Verdelhos et al., 2005). Nevertheless, all species showed adaptive behavioural patterns, related to resource availability and habitat heterogeneity during the macroalgal bloom, with a rapid increase in secondary production at the eutrophic area. After the macroalgal crash, production decreased dramatically, emphasising the instability of the eutrophic area. The macroalgal blooms temporarily benefited the ecosystem, but never replaced the production associated to the seagrasses, as concluded also by Norkko et al. (2000), Cardoso et al. (2002, 2004), Dolbeth et al. (2003), Ferreira et al. (2004), Verdelhos et al. (2005). Also, several differences in the pattern of variation in production were found at species level, mainly due to life cycle characteristics such as voltinism, life spans, or to different abundances in the areas considered (each species will be discussed below). All these natural (e.g., Zostera) or environmentally constrained (eutrophic area) adaptations to the ecosystem may bias estimations of secondary production by empirical methods at community and more obviously at species level. Nevertheless, a good model for estimating secondary production must be applicable to a broad set of conditions. In the present study, there was an attempt to understand the different empirical methods performance, regarding different habitats, catastrophic events (macroalgal bloom) and different species' voltinism, life span and abundances.

Calculation methods such as those based on cohort increment or removal summation, Allen's curve, instantaneous growth, and the size frequency methods 
have been studied and compared (Waters and Crawford, 1973; Cushman et al., 1978; Wildish and Pier, 1981; Benke, 1984; Giberson and Galloway, 1985; Morin et al., 1987). In general, cohort methods were considered as providing similar and more accurate estimates (although with instantaneous growth estimates could be slightly more biased, Cushman et al., 1978; Morin et al., 1987), whereas size frequency methods have been pointed out to over estimate production (Waters and Crawford, 1973; Cushman et al., 1978; Wildish and Pier, 1981; Benke, 1984). Also, cohort increment summation is often used in secondary production studies (Brey, 1990a,b; Benke, 1993; Sprung, 1994; Mistri et al., 2001; Dolbeth et al., 2003), which justifies its use as a benchmark. Yet, the method assumes that the population growth is perfectly synchronous, meaning that a good estimate will depend on how well the growth or the survivorship curve approximates the real one (Benke, 1984; Morin et al., 1987). In the present study, it was not possible to provide confidence limits to the cohort increment summation estimates, using the bootstrapping technique (Morin et al., 1987; Brey, 1990b), due to the large number of multicohort species involved in the calculations (in two different areas and two years). Anyway, assuming those estimates as accurate, a deviation limit lower than a $10 \%$ was assumed to be representative of a good estimate provided by an empirical method, along with the slope and intercept of a linear regression line between the cohort and the empirical methods not significantly different from 1 and 0 , respectively.

Results suggested Brey 4-04 as a good alternative methodology. Nevertheless, the good results for the intertidal species were obtained without computing a value for depth, meaning $0 \mathrm{~m}$, according to the suggestion of Tumbiolo and Downing (1994) for intertidal species. The model is also very easy to apply.

After Brey 4-04, Sprung was the method that gave better responses, yet some important differences could be found, mainly at species level (discussed above), producing different slopes and intercepts. The results strongly depend on the $P / B_{\text {spec }}$ achieved, as seen by the different responses of the two versions of the method. $P / \bar{B}_{\text {spec }} 1$ (Sprung 1) is the best ratio for the species studied, as it was achieved by a cohort method and reflects the ecosystem dynamics for the period of time considered. Accordingly, estimates were better with Sprung 1 than with Sprung 2 (which is the more available form of application of the method).

Robert produced consistent results for the annual productions, in agreement with the findings of Medernach (1999). Yet, this method depends on the correct evaluation of the species life span, which makes it difficult to apply.

Inc Sum assumes that all data represent a single cohort. Negative production is considered zero. This procedure is very easy to apply. Nevertheless, the estimated production may change very drastically as a function of yearly dynamics, as real dynamics of production may not be obtained, since the development of a population is not followed. This means that the results will depend on the species life cycle, as error will certainly increase with species' voltinism and life span.

As a tendency, $S c h w$ and $T \& D$ produced underestimations (very clear with Schw, due slope and intercept in the regression analyse lower than 1 and 0 ). In accordance, the study of Mistri et al. (2001) also provided underestimates for Schw. With regard to $T \& D$, some factors were not taken into account, which probably would increase the method's performance. As example, data on molluscs, used for the equation, did not take into account the shell, which represents an important part of secondary production (Bachelet, 1982).

Huge over-estimations were obtained with $M \& B$. This model was developed using production data of freshwater invertebrates, whose $P / \bar{B}$ ratios can be higher than those from the marine and estuarine invertebrates. This leads in general to higher productions (Morin and Bourassa, 1992). Facing the present results, this method may not be advisable for marine or estuarine species, as it has already been applied in other studies (Cartes and Sorbe, 1999).

\subsection{Systematic considerations}

All empirical methods worked better if used for the sum of the species, which has been recommended by some authors (Brey, 1990a). Anyway, it is important to understand how estimates varied among species life cycles and abundances within the sampling areas, so that potential deviations to the Cohort estimates may be known. 
Hydrobia ulvae is a dominant species in the Zostera bed. It has 4 recruitments per year (Lillebø et al., 1999; Cardoso et al., 2002). At the Zostera bed, this species maximizes its reproduction and growth, which are translated into high Cohort productions with high natural variations. In contrast, the eutrophic area was an alternative habitat, especially during the macroalgal bloom, where this species showed an opportunistic behaviour, related with food resources (Cardoso et al., 2002). In accordance, almost all methods showed high residuals for this species in the Zostera, which were especially high with Sprung, Schw and $M \& B$ methods. In contrast, better annual production and lower residuals were observed in the eutrophic area, as the effects of voltinism are not so visible and production was low during the whole year. Brey 404 produced the best estimates for this species.

Cyathura carinata is a dominant species in the eutrophic area and consequently had higher Cohort production there. Its production increased substantially during the macroalgal bloom, but decreased soon after, being more stable in 1994. At the Zostera bed, its production was relatively low and was related with high parasite pressure in the Zostera, which inhibits reproduction and turns population more erratic (Jensen et al., 2004). This species has only one cohort per year (Ferreira et al., 2004). Accordingly, with the exception of $M \& B$ and $S c h w$, all methods seemed to provide reasonable estimates, with deviations between 0 and 20\%. Inc Sum, along with Brey 4-04, showed the best response to production variation and annual estimates of $C$. carinata, yet residuals were high in Zostera 1993.

Scrobicularia plana is a long-lived species, which has one single cohort per year (Verdelhos et al., 2005). Production was relatively low, with the highest values in the eutrophic area in 1993, during the algal bloom, but decreasing afterwards. Yet the potential production can be much higher, as seen by Dolbeth et al. (2003), due to the fact that juveniles $(<4 \mathrm{~mm})$ were not used for the estimates. Anyway, the long-term effects of macroalgae on the production were harmful, as seen by Verdelhos et al. (2005). The worst estimates of the empirical methods were obtained for this slow-growing species, with comparatively high individual biomass. High deviations were obtained, especially with Inc Sum with high residuals, followed by $M \& B$ and the remaining methods. Even Brey 4-04 produced high deviations, especially for the Zostera bed and the eutrophic area in 1994, where production was very low.

Both Ampithoe valida and Melita palmata had very low productions in both areas. This reflects in a higher possibility of deviations if the secondary production is analysed for each single species, as it deals with very low absolute values. Accordingly, almost all methods showed high deviations, especially $M \& B$. Yet, the effect of these high deviations is lessened when species are pooled for the computation of community production, as seen by the low residuals values of these two species, especially for Sprung and Schw. So, whenever in community production studies low abundant and rare species appear, the optimal empirical method should be the easiest one to apply, as the estimates have more or less the same degree of variation and the sum of all less representative species may smooth deviations.

\section{Conclusions}

Empirical production methods are effective for the synthesis of data and as predictive tools, when cohort, size frequency methods or mass growth methods are not applicable. The empirical methods that took into account population and environmental parameters performed more satisfactorily if used for a sum of species. Also, species life history and abundance in the study area are quite important for the choice of method. Within a community, biased production estimates of empirical methods potentially increase if the community is dominated by single species, especially if these are fast-growing and multicohort species. In fact, if $H$. ulvae estimates were eliminated from the regression analysis the slopes and intercepts would be much closer to the reference values ( 1 and 0 ), meaning closer empirical estimates to the cohort increment summation estimates (e.g., Sprung $1=1.045$ Cohort-0.746, $R^{2}=0.95$, for $n=16$ ). Among empirical methods, Brey (2001) version 4-04 method was considered the best alternative methodology. Sprung (1993) method can also provide reasonable results. Yet, $P / \bar{B}$ ratios of all species in a community can be difficult to obtain, especially for less abundant and rare species. In these cases, the sum of biomass increases from consecutive sampling dates (Inc Sum) may be applied. 


\section{Acknowledgments}

This work was supported by the F.C.T. (Portuguese Foundation for Science and Technology) through a $\mathrm{PhD}$ grant to $\mathrm{M}$. Dolbeth (SFRH/BD/ 14112/2003). [RH]

\section{References}

Bachelet, G., 1982. Quelques problèmes liés à l'estimation de la production secondaire. Cas des bivalves Macoma balthica et Scrobicularia plana. Oceanol. Acta 4 (5), 421-431.

Banse, K., Mosher, S., 1980. Adult body mass and annual production/biomass relationships of field populations. Ecol. Monogr. 50 (3), 355-379.

Benke, A.C., 1984. Secondary production of aquatic insects. In: Resh, V.H., Rosenberg, D.M. (Eds.), Ecology of Aquatic Insects. Praeger, New York, pp. 289-322.

Benke, A.C., 1993. Concepts and patters of invertebrate production in running waters. Verh. Internat Verein. Limnol. 25, 15-38.

Brey, T., 1990a. Estimating productivity of macrobenthic invertebrates from biomass and mean individual weight. Meeresforschung 32, 329-343.

Brey, T., 1990b. Confidence limits for secondary production estimates: application of the bootstrap to the increment summation method. Mar. Biol. 106, 503-508.

Brey, T., 2001. Population Dynamics in Benthic Invertebrates. A Virtual Handbook. Version 01.2. http://www.awi-bremerhaven. de/Benthic/Ecosystem/FoodWeb/Handbook/main.html. Alfred Wegener Institute for Polar and Marine Research, Germany.

Cardoso, P.G., Lillebø, A.I., Pardal, M.A., Ferreira, S.M., Marques, J.C., 2002. The effects of different primary producers on Hydrobia ulvae population dynamics: a case study in a temperate intertidal estuary. J. Exp. Mar. Biol. Ecol. 277 (2), 173-195.

Cardoso, P.G., Pardal, M.A., Lillebø, A.I., Ferreira, S.M., Raffaelli, D., Marques, J.C., 2004. Dynamic changes in seagrass assemblages under eutrophication and implications for recovery. $\mathrm{J}$. Exp. Mar. Biol. Ecol. 302, 233-248.

Cartes, J.E., Sorbe, J.C., 1999. Estimating secondary production in bathyal suprabenthic peracarid crustaceans form the Catalan Sea slope (western Mediterranean; 391-1255 m). J. Exp. Mar. Biol. Ecol. 239, 195-210.

Crisp, D.J., 1984. Energy flow measurements. In: Holme, N.A., McIntyre, A.D. (Eds.), Methods for the Study of Marine Benthos, 2nd ed. Blackwell Scientific Publications, Norfolk, pp. $284-372$.

Cushman, R.M., Shugart, H.H., Hildebrandt, S.G., Elwood, J.W., 1978. The effect of growth curve and sampling regime on instantaneous-growth, removal-summation, and Hynes/Hamilton estimates of aquatic insect production: a computer simulation. Limnol. Oceanogr. 23, 184-189.

Dolbeth, M., Pardal, M.A., Lillebø, A.I., Azeiteiro, U.M., Marques, J.C., 2003. Short and long-term effects of eutrophication on the secondary production of an intertidal macrobenthic community. Mar. Biol. 143, 1229-1238.

Edgar, G.J., Shaw, C., Watson, G.F., Hammond, L.S., 1994. Comparisons of species richness, size-structure and production of benthos in vegetated and unvegetated habitats in Western Port, Victoria. J. Exp. Mar. Ecol. 176, 201-226.

Ferreira, S.M., Pardal, M.A., Lillebø, A.I., Cardoso, P.G., Marques, J.C., 2004. Population dynamics of Cyathura carinata (Isopoda) in a eutrophic temperate estuary. Est. Coast. Shelf Sci. 61, 669-677.

Giberson, D.J., Galloway, T.D., 1985. Life history and production of Ephoron album (Say) (Ephemeroptera: Polymitarcidae) in the Valley river, Manitoba. Can. J. Zool. 63, 1668-1674.

Heck, K.L., Able, K.W., Roman, C.T., Fahay, M.P., 1995. Composition, abundance, biomass, and production of macrofauna in a New England estuary - comparisons among eelgrass beds and other nursery habitats. Estuaries 18 (2), 379-389.

Jensen, K.T., Ferreira, S.M., Pardal, M.A., 2004. Trematodes in a Cyathura carinata population from a temperate intertidal estuary: infection patterns and impact on host. J. Mar. Biol. Assoc. U.K. 84, 1151-1158.

Lillebø, A.I., Pardal, M.A., Marques, J.C., 1999. Population structure, dynamics and production of Hydrobia ulvae (Pennant) (Mollusca: Prosobranchia) along an eutrophication gradient in the Mondego estuary (Portugal). Acta Oecol. 20 (4), 289-304.

Medernach, L.G.A., 1999. Comparaison de méthodes d'évaluation de la production secondaire d'une population de l'annélide polychète Ditrupa arietina (O.F. Muller). Oceanol. Acta 22 (3), 337-352.

Mistri, M., Fano, E.A., Rossi, R., 2001. Macrofaunal secondary production in a lagoon of the Po River Delta: an evaluation of estimation methods. Ital. J. Zool. 68, 147-151.

Morin, A., 1997. Empirical models predicting population abundance and productivity in lotic systems. J. N. Am. Benthol. Soc. 16 (2), 319-337.

Morin, A., Bourassa, N., 1992. Modèles empiriques de la production annuelle et du rapport $\mathrm{P} / \mathrm{B}$ d'invertébrés benthiques d'eau courante. Can. J. Fish Aquat. Sci. 49, 532-539.

Morin, A., Mousseau, T.A., Roff, D.A., 1987. Accuracy and precision of secondary production estimates. Limnol. Oceanogr. 32, $1342-1352$.

Nogueira, A.J.A., 1992. ANAMOD - Extracção dos Componentes Modais de Distribuições de Frequência de Variáveis Biométricas. Trabalho de Síntese Apresentado para Prestação de Provas de Aptidão Pedagógica e Capacidade Científica, University of Coimbra. $67 \mathrm{pp}$.

Norkko, A., Bonsdorff, E., Norkko, A., 2000. Drifting algal mats as an alternative habitat for benthic invertebrates: species specific responses to a transient resource. J. Exp. Mar. Biol. Ecol. 248, $79-104$

Pardal, M.A., Marques, J.C., Metelo, I., Lillebø, A.I., Flindt, M.R., 2000. Impact of eutrophication on the life cycle, population dynamics and production of Ampithoe valida (Amphipoda) along an estuarine spatial gradient (Mondego estuary, Portugal). Mar. Ecol. Prog. Ser. 196, 207-219.

Pardal, M.A., Marques, J.C., Metelo, I., Lillebø, A.I., Flindt, M.R., 2002. Impact of eutrophication on amphipods Melita 
palmata and Ampithoe valida in the Mondego estuary. In: Pardal, M.A., Marques, J.C., Graça, M. (Eds.), Aquatic Ecology of the Mondego River Basin. Global Importance of Local Experience. Imprensa da Universidade, Coimbra, pp. 457-472.

Pardal, M.A., Cardoso, P.G., Sousa, J.P., Marques, J.C., Raffaelli, D., 2004. Assessing environmental quality: a novel approach. Mar. Ecol. Prog. Ser. 267, 1-8.

Robertson, A.I., 1979. The relationship between annual production: biomass ratios and life spans for marine macrobenthos. Oecologia 38, 193-202.

Schwinghamer, P., Hargrave, B., Peer, D., Hawkins, C.M., 1986. Partioning of production and respiration among size groups of organisms in an intertidal benthic community. Mar. Ecol. Prog. Ser. $31,131-142$.

Sokal, R.R., Rohlf, F.J., 1981. Biometry. The Principles and Practice of Statistics in Biological Research, 2nd ed. Freeman and Company, New York, p. 859.

Sprung, M., 1993. Estimating macrobenthinc secondary production from body weight and biomass: a field test in a non-boreal intertidal habitat. Mar. Ecol. Prog. Ser. 100, 103-109.
Sprung, M., 1994. Macrobenthic secondary production in the intertidal zone of Ria Formosa - a lagoon in Southern Portugal. Est. Coast Shelf Sci. 38, 539-558.

Tedeschi, L.O., 2004. Assessment of the adequacy of mathematical models, Department of Animal Science. Cornell University, Ithaca, NY 14850. http://www.cncps.cornell.edu/modeval/ modeval_web.htm.

Tumbiolo, M.L., Downing, J., 1994. An empirical model for the prediction of secondary production in marine benthic invertebrate populations. Mar. Ecol. Prog. Ser. 114, 165-174.

Verdelhos, T., Neto, J.M., Marques, J.C., Pardal, M.A., 2005. The effect of eutrophication and coastal management on the bivalve Scrobicularia plana. Est. Coast. Shelf Sci. 63, 261-268.

Waters, T.F., Crawford, G.W., 1973. Annual production of a stream mayfly population: a comparison of methods. Limnol. Oceanogr. 18, 286-296.

Wildish, D.J., Pier, D., 1981. Methods for estimating secondary production in marine Amphipoda. Can. J. Fish. Aquat. 38, 1019-1026.

Winberg, G.G., 1971. Methods for the Estimating of Production of Aquatic Animals. Academic Press Inc, London. 